\title{
EDUKASI TENTANG PENULARAN DAN PENCEGAHAN COVID-19 SERTA PEMBAGIAN MASKER KEPADA MASYARAKAT DUSUN III DESA SEI ROTAN
}

\author{
Khodijah Tussolihin Dalimunthe ${ }^{1}$, Athaillah ${ }^{2}$, Vina Anggina Hutasuhut ${ }^{3}$ \\ ${ }^{1,2,3}$ Dosen Universitas Haji Sumatera Utara, Medan, Indonesia \\ khodijahtussolihin27@gmail.com, atha8237@gmail.com, anggina25@gmail.com
}

\begin{abstract}
ABSTRAK
Permasalahan di masyarakat yaitu masih banyak yang belum paham tentang penularan dan pencegahan covid-19. Sehingga banyak di antara masyarakat yang mengacukan protokol kesehatan. Padahal kondisi saat ini sangat dibutuhkan kesadaran seperti pentingnya menggunakan masker ketika keluar rumah, cuci tangan pakai sabun, dan menjaga jarak. Kebiasaan untuk menerapkan perilaku hidup bersih dan sehat bukan hal mudah di sebagian kalangan masyarkat., Membutuhkan pemahaman dan motivasi untuk disiplin dalam menerapkannya. Tujuan pengabdian adalah memberikan informasi tentang cara penularan dan bagaimana cara mencegah covid-19. Kegiatan dilaksankan secara door to door kepada masyarakat memberikan edukasi tentang penularan dan pencegahan covid-19 serta membagikan masker. Jenis pengabdian ini adalah promosi kesehatan dengan menggunakan metode ceramah serta pembagian leafleat. Pelaksanaan kegiatan ini dapat menambah pengetahuan masyarakat tentang bagaimana cara penularan dan pencegahan covid-19, sehingga masyarakat menjadi lebih sadar dan semakian disiplin dalam menjalankan protokol kesehatan seperti menggunakan masker, mencuci tangan pakai sabun dan selalu menjaga jarak.
\end{abstract}

Kata kunci: Covid-19, Pembagian Masker

\section{ABSTRAK}

The problem in society is that there are still many who do not understand about the transmission and prevention of COVID-19. So many of the people who refer to health protocols. Even though the current conditions really need awareness such as the importance of using masks when leaving the house, washing hands with soap, and maintaining distance. The habit of implementing clean and healthy living behavior is not an easy thing in some circles of society. It requires understanding and motivation to be disciplined in implementing it. The purpose of the service is to provide information about how to transmit and how to prevent covid-19. The activity was carried out door to door to the public providing education about the transmission and prevention of COVID-19 and distributing masks. This type of service is health promotion using the lecture method and the distribution of leaflets. The implementation of this activity can increase public knowledge about how to transmit and prevent COVID-19, so that people become more aware and more disciplined in carrying out health protocols such as using masks, washing hands with soap and always keeping a distance.

Keywords: Covid-19, Mask Distribution 


\section{PENDAHULUAN}

Kasus Covid-19 pertama kali dilaporkan di Indonesia pada tanggal 2 Maret 2020 sejumlah dua kasus. Data 31 Maret 2020 menunjukkan kasus yang terkonfirmasi berjumlah 1.528 kasus dan 136 kasus kematian. Tingkat mortalitas Covid-19 di Indonesia sebesar $8,9 \%$, angka ini merupakan yang tertinggi di Asia Tenggara. Data terbaru pada tanggal 23 April 2020 kasus terkonfirmasi positif sebanyak 7.775 kasus dengan 647 kematian (covid19.go.id). Saat ini, penyebaran SARS-CoV-2 dari manusia ke manusia menjadi sumber transmisi utama sehingga penyebaran menjadi lebih agresif. Transmisi SARS-CoV-2 dari pasien simptomatik terjadi melalui droplet yang keluar saat batuk atau bersin.

Sejak ditetapkannya negara Indonesia sebagai darurat bencana corona berdasarkan saran dari WHO, maka pemerintah mengambil beberapa langkah yang ditetapkan sebagai kebijakan untuk pencegahan penularan Covid-19 ini yaitu dengan membatasi aktifitas keluar rumah, kegiatan sekolah dirumahkan, bekerja dari rumah (work from home), bahkan kegiatan beribadah pundirumahkan. Hal ini sudah menjadi kebijakan pemerintah berdasarkan pertimbanganpertimbangan yang sudah melalui analisa yang mendalam. Kebijakan ini diharapkan mampu mengatasi masalah yang terjadi di masyarakat yang berorientasi pada pemenuhan kebutuhan dan kepentingan masyarakat.

Permasalahan di masyarakat masih banyak yang belum paham pencegahan penularan covid19 ini diantaranya pentingnya menggunakan masker ketika keluar rumah, pentingnya personal hygiene, cuci tangan pakai sabun, dan pyshical distancing. Kebiasaan untuk menerapkan perilaku hidup bersih dan sehat bukan hal mudah, membutuhkan pemahaman dan motivasi dari individu sehingga setiap individu lebih disiplin dalam menerapkannya. Kegiatan pengabdian dilaksanakan agar masyarakat mendapatkan informasi tentang cara penularan dan pencegahan covid-19. Sehingga masyarakat menjadi disiplin dalam menjaga protokol kesehatan seperti menggunakan masker.

\section{METODE}

Pelaksanaan kegiatan dilakukan dengan sasaran adalah masyarakat yang berlokasi di Dusun III Sei Rotan Kecamatan Batang Kuis. Sebelum melaksanakan kegiatan terlebih dahulu melakukan koordinasi kepada Kepala Lingkungan dan meminta izin untuk melaksanakan kegiatan. Kegiatan dilaksankan secara door to door kepada masyarakat Memberikan edukasi tentang penularan dan pencegahan covid-19 serta membagikan masker. Kegiatan dilaksanakan selama dua hari yaitu 14 dan 15 November 2020 .

Jenis pengabdian ini adalah promosi kesehatan dengan metode yang digunakan adalah metode ceramah dengan pembagian leafleat, yaitu menyampaikan materi tentang cara penularan dan pencegahan covid-19 kepada masyarakat menggunakan media leafleat agar masyarakat mudah memahami materi yang disampaikan. Sebelum penyampain materi, dilakukan pembagian masker kepada masyarakat terlebih dahulu. 


\section{HASIL DAN PEMBAHASAN}

Tridharma perguruan tinggi merupakan kegiatan yang wajib yang harus dilaksanakan dosen yaitu mengajar, melaksanakan penelitian dan pengabdian. Pengabdian salah satu kegiatan dosen yang bertujuan untuk menerapkan ilmu pengetahuan yang diperoleh dengan memberikan edukasi kepada masyarakat, khususnya masyarakat Dusun III Percut Sei Tuan. Dosen yang mengajar di jurusan Kesehatan masyarakat Univerersitas Haji Sumatera Utara memberi edukasi kepada masyarakat tentang pentingnya mengetahui penularan. Sehingga kita bisa mencegah lebih awal. Sehingga, diperlukan kesadaran yaitu meematuhi protokol kesehatan salah satunya menggunakan masker dan berperilaku hidup bersih dan sehat.

Kegiatan yang dilakukan door to door yang bertujuan untuk mengurangi kerumunan dimasa pandemi, masyarakat sangat antusias mendengar ceramah sehingga mereka tertarik terus bertanya. Ada juga sebagian masyarakat yang tidak tahu tentang covid-19. Akan tetapi, dengan adanya kegiatan ini akan memberikan pengetahuan tentang penularan dan pencegahan covid-19. Kegiatan berlangsung dengan kondusif dengan respon yang baik dari masyarakat.
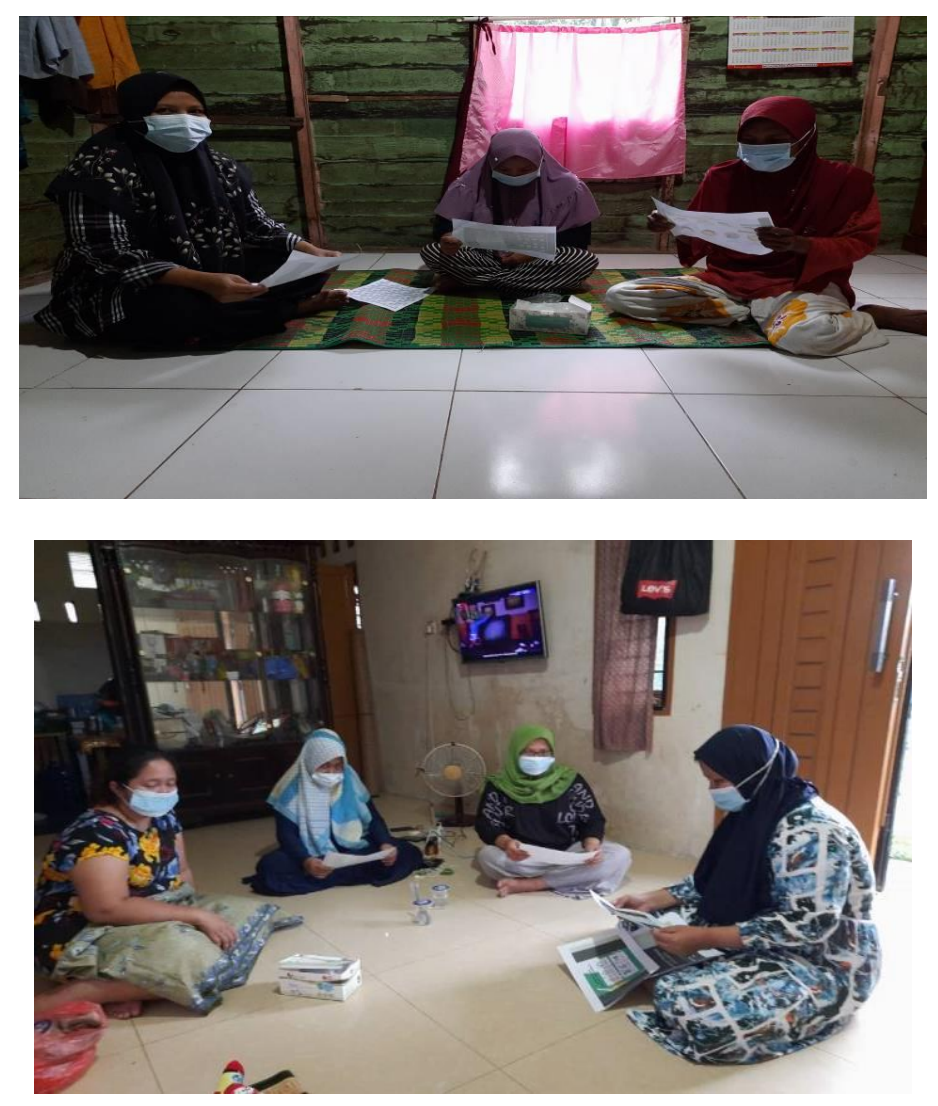

Gambar 2. Penyuluhan tentang Penularan dan Pencegahan Covid-19 dan Membagikan Masker 


\section{KESIMPULAN}

Informasi tentang pencegahan covid-19 dapat tersampaikan dengan baik kepada masyarakat di Dusun III Desa Sei Rotan Kecamatan Percut Sei Tuan. Masyarakat juga menyadari pentingnya mencuci tangan menggunakan sabun dan menggunakan masker untuk mencegah penularan covid-19. Serta mengikuti arahan tentang cara mencuci tangan dan cara penggunaan masker yang baik dan benar. Masyarakat menyadari pentingnya menerapkan protokol kesehatan untuk mencegah penularan covid-19.

\section{REFERENSI}

Gugus Tugas Percepatan Penanganan Covid-19. Data Sebaran Virus Corona di Indonesia Update 01 November 2020. https://www.covid19.go.id/

Handayani, D., Hadi, D. R., Isbaniah, F., Burhan, E., \& Agustin, H. (2019). Corona Virus Disease 2019. Jurnal Respirologi Indonesia, Diakses 02 desember 2020. https://jurnalrespirologi.org/index.php/jri/article/view/101.

Infeksi Emerging. Media Informasi Resmi Terkini Penyakit Infeksi Emerging diakses 20 januari 2021 https://infeksiemerging.kemkes.go.id/

Kementerian Kesehatan Republik Indonesia. Pedoman Pemberdayaan Masyarakat dalam Pencegahan COVID-19 di RT/RW/Desa. Diakses 20 Januari 2021. https://infeksiemerging.kemkes.go.id/download/BUKU_PEDOMAN_RT_RW_ Pencegahan_COVID.pdf.

Keputusan Kesehatan Republik Indonesia Nomor HK.01.07/Menkes/413/2020 Tentang Pedoman Pencegahan dan Pengendalian Coronavirus. Diakses 20 Januari 2021.https://covid19.go.id/p/regulasi/keputusan-menteri-kesehatan-republikindonesia-nomor-hk0107menkes4132020.

Khariri, K. (2020). Sosialisasi bahaya dan upaya pencegahan infeksi corona virus disease (COVID-19) di Kelurahan Koja, Jakarta Utara. INDRA: Jurnal Pengabdian Kepada Masyarakat. Diakses tanggal 23 Januari 2021. https://jffk.unram.ac.id.

Komite Penanganan Covid-19 dan Pemulihan Ekonomi Nasional. Diakses 23 Januari 2021. https://covid19.go.id/.

Nur Rohim Yunus, Annissa Rezki (2020). Kebijakan Pemberlakuan Lock Down Sebagai Antisipasi Penyebaran Corona Virus Covid-19 Jurnal Sosial dan Budaya. Diakses 23 Januari 2021. http://journal.uinjkt.ac.id/index.php/salam/article/view/1508.

Sumut tanggap Covid-19. Berita Terbaru Sumut. Diakses Tanggal 23 Januari 2021. https://covid19.sumutprov.go.id/

World Health Organization. Coronavirus disease (COVID-19) pandemic. Diakses tanggal 20 Januari 2021. https://www.who.int/emergencies/diseases/novelcoronavirus2019?gclid=EAIaIQobChMI8qzTjJDj8QIVqtxMAh19igP8EAAYAS AAEgL8tvD_BwE. 